\title{
UPAYA PENINGKATAN EKONOMI PONDOK PESANTREN MELALUI PENDIDIKAN EKONOMI SYARIAH BAGI GENERASI PEMUDA MUSLIM DI MADURA DENGAN EKSTRAKULIKULER SMA
}

\author{
Mohammad Zainal, Ahmad Ghufron \\ Ekonomi Syariah STAIMU Pamekasan \\ zainputra986@gmail.com
}

\begin{abstract}
Abstrak
Pendidikan ekonomi Islam di Indonesia sangat penting karena pertumbuban industri keuangan syariah yang berkembang pesat. Jadi pengenalan ekonomi ilabi pada generasi muda, yaitu pada periode sebelum kuliah penting dilakukan. Konsep integrasi pendidikan ekonomi Islam dengan ekstrakurikuler koperasi siswa adalah strategi yang efektif mencetak generasi muda muslim yang faham ekonomi Islam. Fokus penelitian ini bagaimana mengkonsep integrasi keilmuan ekonomi syariah di lingkungan pondok pesantren berbasis SMA melalui ekstrakulikuler yang bersinergi dengan koperasi pondok pesantren.

Penulisan karya ilmiah ini dilakukan dengan studi literatur yang mendalam, yakni dengan menggunakan penulisan kualitatif deskriptif. Metode pengumpulan data dengan metode kepustakaan dan dokumenter. Proses analisis data yang dilakukan dalam penulisan ini terdiri dari: pengumpulan data (data collection), reduksi data (data reduction), penyajian data (data display), analisis dan Pembahasan.

Hasil penelitian menemukan bahwa implementasi ekonomi syariah di level sekolah menengah bukanlah hal yang mudah, dikarenakan belum adanya kurikulum dan terbatasnya SDI pengajar yang mempunyai kualifikasi keilmuan yang integral. Konsep pengintegrasian pendidikan ekonomi syariah dengan ekstrakulikuler koperasi siswa adalah upaya strategis untuk melabirkan SDI muda nan tanggub dalam bidang ekonomi syariah. Hal ini dikarenakan pemilihan dalam penerapan teoritis secara aplikatif sebagai pilot project dianggap sangat mendukung ikelim pengajaran ekonomi syariah.
\end{abstract}

Kata kunci: Pendidikan ekonomi Islam, koperasi sekolah asrama, pemuda SDI 


\section{PENDAHULUAN}

Indonesia adalah negara kelima dengan populasi terbesar di dunia sekaligus negara pertama dengan populasi muslim terbesar di dunia (Unggul, 2016), ia memiliki karakteristik berupa keragaman pola hidup dan budaya. Faktor kuantitas ini ternyata belum dibarengi dengan pengembangan kualitas individunya terutama pendidikan sebagai sumber penempaan sumber daya manusia yang paling konkrit. Hal ini tentu sangat riskan mengingat perkembangan ilmu pengetahuan dan teknologi sudah semakin maju, terutama menyangkut relevansi dengan kebutuhan tenaga kerja yang sudah semakin dinamis, yang tentunya menuntut sumber daya manusia yang profesional secara teknis dan filosofis agar Indonesia dapat menjadi bangsa yang mampu bersaing dikompetisi global. Hal ini menyadarkan banyak pihak bahwa membangun sebuah sistem pendidikan ekonomi syariah menjadi sebuah keniscayaan bagi perkembangan ekonomi syariah ke depan. Sehingga ekonomi syariah tidak lagi tenggelam dan mampu terus berkembang menjadi sebuah sistem yang relevan dan kontekstual (Basri, Samin, \& Beik, 2019).

Perkembangan pendidikan ekonomi syariah pun mengalami momentum kebangkitannya. Ini terlihat dari mulai banyaknya universitas di berbagai negara membuka jalur-jalur khusus ekonomi syariah. Di mana tidak hanya negara-negara syariah atau penduduknya mayoritas muslim yang mengembangkannya, akan tetapi negara-negara maju seperti Inggris pun mulai tertarik memelajari ilmu ekonomi syariah. Di Inggris terdapat beberapa universitas yang mengembangkan kajian ekonomi syariah, misalnya University of Durham, University of Portsmouth, Markfield Institute of Higher Education, University of Wales Lampeter, dan Loughborough University. Bahkan salah satu Universitas paling terkemuka di dunia, yaitu Harvard University, sangat aktif melakukan kajian ekonomi syariah. Tidak jarang literatur hingga jurnal-jurnal ekonomi islam disusun oleh ekonom-ekonom dari barat. Kegiatan pertemuan tahunan pun sering dilaksanakan oleh universitas-universitas tersebut.

Di Indonesia, pendidikan ekonomi syariah menjadi semakin populer terlebih setelah terjadi krisis Asia 1997. Di mulai dari berdirinya institusi perbankan yang berbasis syariah dalam operasionalnya sebelum krisis, hal ini terus diikuti dengan berkembangnya institusi sejenis hingga momentum krisis 1997 tiba. Kita bersyukur bahwa sudah banyak perguruan tinggi (PT) yang mengajarkan ekonomi syariah di tanah air. Beberapa lembaga bahkan fokus menjadi Sekolah Tinggi Ekonomi Islam (STEI) seperti STEI SEBI, STEI Tazkia dan STEI Yogyakarta. Sedangkan beberapa universitas besar telah membuka konsentrasi ekonomi syariah seperti UI, Unair, IPB, UIN Jakarta, UIKA Bogor, Universitas Trunojoyo Madura dan sebagainya. Selain itu program pasca sarjana juga banyak ditawarkan seperti di PSKTTI UI, UIKA Bogor, Trisakti untuk program Magister, dan bahkan Unair, Trisakti dan UIN Jakarta sudah menawarkan sampai program Doktoral.

Merealisasikan pendidikan ekonomi syariah pada tingkat pra-kuliah atau masa sekolah menengah amatlah perlu dikarenakan proses internalisasi nilai-nilai ekonomi syariah dalam aktivitas hidup akan lebih efektif jika diajarkan lebih dini sebelum masa kuliah (Niswatin, Hasiru, \& Rasuli, 2017). Hal ini dikarenakan proses belajar tidaklah hanya transfer of knowledge tapi juga transfer of value. Dalam jenjang Sekolah menengah saat ini pendidikan ekonomi masih 
didominasi oleh worldview dan muatan ideologi kapitalisme (Ahyar, 2018). Dan hal ini yang menjadi akar kerusakan yang dahsyat dalam perekonomian dan ini tentunya membutuhkan sebuah perubahan yang serius dan fundamental.

Harapannya ingin mewujudkan realisasi pendidikan ekonomi syariah pada SMA Sederajat baik dalam tataran teoritis dan praktis di pondok pesantren cukup mumpuni apabila realisasi tersebut diterapkan di lingkungan pondok pesantren di Madura . Madura yang dikenal sebagai pulau garam yang khas akan santri harus mampu memberikan konstribusi dalam mencetak sumber daya insani yang berkompeten. Maka dengan adanya pengajaran ilmu ekonomi syariah maka diharapkan pihak sekolah di pesantren mengaplikasikan pendidikan ekonomi syariah dalam muatan kurikulum pelajaran. Serta memperan aktifkan pengetahuan secara teoritis tersebut bisa dipraktiskan pada ekstrakulikuler koperasi pondok pesantren yang akan dapat menghasilkan lulusan yang kompeten meskipun baru pada taraf sekolah menengah.

\section{TINJAUAN PUSTAKA}

\section{Urgensi Kurikulum Pendidikan Ekonomi Syariah}

Perkembangan yang cepat dari industri keuangan dan perbankan syariah saat ini tentu membutuhkan Sumber Daya Insani (SDI) profesional dan berkualitas yang mampu mengetahui tidak hanya tataran konseptual tetapi juga pada tataran praktis tentang ekonomi keuangan syariah tersebut (Muliadi, 2018). Kebutuhan akan Sumber Daya Insani tersebut, sampai saat ini belum diimbangi dengan supply SDI yang memadai dari dunia pendidikan. Pada tataran teoritis dan konseptual, kita masih merasakan sangat kekurangan pakar yang benar-benar mendalami sekaligus ilmu ushul fiqh, fikih muamalah dan ilmu ekonomi keuangan. Figur seperti ini benar-benar langka bukan saja bagi masyarakat Islam di Indonesia melainkan juga di banyak negara termasuk negara lain yang perkembangan ekonomi syariahnya cukup pesat. Kebanyakan dari para pakar ekonomi adalah mereka yang fasih berbicara tentang ilmu ekonomi tetapi awam dalam ushul fiqh atau figh muamalah dan sebaliknya. Persoalan ini memang bukan hanya persoalan akademik yang pemecahannya harus melibatkan perubahan dalam pengembangan kurikulum dan silabi pengajaran Ekonomi Syariah, akan tetapi juga persoalan-persoalan birokrasi dan political will, termasuk di dalamnya sistem pendidikan yang ada (Effiyanti, Pratiwi, \& Dalimunthe, 2018).

Upaya pengembangan prodi atau konsentrasi ekonomi syariah kini hanya dilakukan secara oleh perguran tinggi itupun masih berjalan sendiri-sendiri, sehingga menimbulkan perbedaan kurikulum yang diajarkan. Karena alasan tersebut, maka diadakanlah symposium kurikulum ekonomi syariah oleh IAEI (Ikatan Ahli Ekonomi Islam) yang akhirnya menghasilkan suatu rekomendasi kurikulum nasional ekonomi syariah yang dapat menjadi standar acuan, yaitu kurikulum ekonomi syariah yang dinamis dan berbasis kompetensi, namun upaya ini masih berhenti pada tataran teoritis dan masih butuh dukungan konkrit opemerintah dalam usaha untuk mengimplementasikannya pada perguruan tinggi.

Praktek menajemen sekolah yang telah berusaha menerapkan internalisasi pesanpesan Islami secara sistematis dan struktural dalam dunia akademik salah satunya adalah yang 
dilakukan oleh yayasan Al-Qudwah Depok yang menerapkan pendidikan Islami dalam satu kompleks dengan sistem boarding shcool. Ia membuka lembaga pendidikan dari tingkat dasar hingga perguruan tinggi sehingga dapat menghasilkan sumber daya insani yang unggul secara duniawi maupun ukhrowi.

Selain itu Menurut Muliadi (2018), kurikulum studi ekonomi syariah setidaknya memiliki tiga paket silabus. Pertama, kurikulum mata kuliah yang netral secara keilmuan dan tidak ada kaitannya dengan Islam. Misalnya matematika, akuntansi, metodologi riset dan semacamnya. Mata kuliah di atas dibutuhkan untuk pembelajaran apa pun karena sifatnya sebagai media analisis dan penghitungan. Kedua, paket mata kuliah yang khusus tentang Islam. Misalnya, Al Quran, Hadis, Fikih, dan lain sebagainya. Pelajaran ini, penting diberikan karena bersifat sebagai pondasi bagi diterapkannya perekonomian Islam. Paket ketiga adalah mata kuliah dan silabus yang khusus mengupas tentang ekonomi syariah, baik makro maupun mikro. Misalnya, perbankan syariah, prinsip-prinsip mudarobah dan murabah, riba dan lain-lain.

Selain itu disitus Pusat Komunikasi Ekonomi Syariah (PKES) dinyatakan bahwa Semakin dini suatu ilmu diberikan, semakin terinternalisasi ilmu tersebut pada orang yang bersangkutan. Tak terkecuali ekonomi syariah yang kini tengah berkembang pesat di Indonesia sedang memerlukan Sumber Daya Insani (SDI) yang tidak sedikit.

\section{Koperasi}

Koperasi berasal dari kata Cooperation yang artinya kerjasama. Sedangkan menurut istilah, yang dimaksud dengan koperasi adalah suatu perkumpulam yang dibentuk oleh para anggota peserta yang berfungsi untuk memenuhi kebutuhan para anggota dengan harga yang relatif rendah dan bertujuan memajukan tingkat hidup bersama. Menurut UU No. 25 tahun 1992 tentang perkoperasian. Koperasi adalah badan usaha yang beranggotakan orang-orang atau badan hukum. Koperasi dengan melandaskan kegiatannya berdasarkan prinsip koperasi sekaligus sebagai gerakan ekonomi rakyat yang berdasarkan atas asas kekeluargaan.

Koperasi adalah suatu kumpulan dari orang-orang yang atas dasar persamaan derajat manusia, dengan tidak memandang haluan agama dan politik secara sukarela masuk untuk sekedar memenuhi kebutuhan bersama yang bersifat kebendaan atas tanggungan bersama. Sedangkan koperasi sekolah atau siswa merupakan badan usaha sukarela yang dibentuk oleh pihak sekolah yang untuk mencapai tujuan visi sekolah dalam mencetak karekter stakeholders dengan proses pemberdayaan SDM dan nirlaba yang diatur demi kesejahteraan bersama. Adapun fungsi dan peran koperasi siswa sebagai berikut: Pertama membangun dan mengembangkan potensi dan kemampuan ekonomi anggota (guru dan siswa) khususnya dan seluruh stakeholder d lingkungan sekolah pada umumnya untuk pemberdayaan ekonomi dan sosial. Kedua berperan serta secara aktif dalam upaya mempertinggi kualitas kehidupan bersosial dan bermasyarakat.

\section{Sumber Daya Insani}

Dalam kajian syariah pada sumber daya manusia menemukan istilah yang pas untuk dipakai, yaitu "sumber daya insani”. Sumber daya insani inilah yang akan memberi makna 
pada ekonomi syariah dengan komitmen dan konsisten mengaplikasikannya dalam kehidupan. Merekalah - dengan membumikan ekonomi syariah - yang dapat membawa kesejahteraan khususnya bagi Indonesia. Kajian tentang sumber daya insani akan dimulai dari manusia sebagai makhluk yang sengaja diciptakan oleh Allah SWT. Manusia diciptakan dengan sebaik-baik bentuk. Manusia mempunyai unsur yang lebih lengkap, selain dibekali dengan nafsu juga diberikan akal untuk berpikir, sehingga ia bebas menentukan jalan mana yang akan dipilih, jalan taqwa atau jalan fujur yang diilhamkan kepadanya. Potensi lain yang ada pada manusia adalah rasio/pemikiran, kalbu/hati, ruh/jiwa dan jasmani/raga. Manusia diciptakan oleh Allah adalah untuk mengabdi kepadanya, sebagaimana tercantum dalam Al Quran Surat Adz Dzariyaat (51) ayat 56. Mengabdi artinya menghambakan diri kepada Allah. Penghambaan itu dilakukan dengan ibadah. Ibadah seperti kita ketahui ada ibadah mahdhah yang berkaitan dengan ibadah kepada Allah dan ibadah ,ammah atau muamalah yang berkaitan dengan hubungan manusia dengan lingkungannya. Abdi dan ibadah dalam bahasa Arab berasal dari kata yang serumpun. Dalam Surat Al Baqarah (2) ayat 30, Allah menyebutkan; "Sesunggubnya Aku hendak menjadikan seorang khalifah di muka bumi". Jadi dibumi ini manusia ditugaskan menjadi khalifah-Nya. Khalifah sendiri berarti wakil atau pengganti. Karena tugasnya yang demikian, maka manusia sebagai wakil Allah, tidak diperbolehkan berbuat kerusakan di muka bumi ini.

Tugas sebagai khalifah ini merupakan ujian bagi manusia, apakah ia berhasil atau gagal dalam mengemban misinya. Manusia (al-insan) sebagai khalifah Allah dimuka bumi diberi tanggungjawab dan amanah untuk memeliharan bumi ini, karena kekhususannya dapat membedakan yang baik dan yang buruk, diberi ilmu, akal dan kemampuan. Orang mukmin, yaitu orang Islam dalam al-Qur"en dinyatakan sebagai "khaira ummab", umat terbaik yang menyuruh kepada hal yang mae ruf, mencegah dari hal yang munkar dan beriman kepada Allah. Inilah tantangan bagi setiap muslim untuk menjadi umat yang terbaik di muka bumi ini.

Berdasarkan pertimbangan hal-hal diatas kemudian dikembangkan kajian sumber daya manusia dari kacamata Islam, yang lazim diperkenalkan dengan istilah sumber daya insani. Dalam kajian sumber daya insani, manusia sebagai sumber daya penggerak suatu proses produksi, harus mempunyai karakteristik atau sifat-sifat yang diilhami dari shifatul anbiyaae atau sifat-sifat para nabi. Sifat-sifat tersebut dapat disingkat dengan SIFAT pula, yaitu : shiddiq (benar), itqan (profesional), fathanah (cerdas), amanah (jujur/terpercaya) dan tabligh (transparan). Profesional secara syariah artinya mengelola suatu usaha/kegiatan dengan amanah. Profesionalisme dalam Islam dijelaskan dalam Al Quran Suat Al Qashash ayat 26.

Dalam bisnis yang Islami dua faktor yang menjadi kata kunci adalah kejujuran dan keahlian. Yusuf Qaradhawi (2002) mengatakan al amanah/kejujuran merupakan puncak moralitas iman dan karakteristik yang paling menonjol dari orang-orang yang beriman. Suatu motto dalam manajemen sumber daya manusia adalah menempatkan orang yang tepat pada posisi yang tepat atau the right man on the right place. Al Quran dalam Surat Al Anfal ayat 27 menyebutkan tentang penempatan pegawai, bahwa seseorang tidak boleh berkhianat dalam menunaikan amanahnya padahal mereka adalah orang yang mengetahui. Demikian juga dalam Surat An Nisaa ${ }^{e e}$ ayat 58, Allah menyatakan: Sesungguhnya Allah menyuruh kamu 
menyampaikan amanat kepada yang berhak menerimanya, dan (menyuruh kamu) apabila menetapkan hukum di antara manusia supaya kamu menetapkan dengan adil. Sesungguhnya Allah memberi pengajaran yang sebaik-baiknya kepadamu. Sesungguhnya Allah adalah Maha mendengar lagi Maha melihat. Dalam ayat diatas menyampaikan amanat kepada yang berhak menerimanya bermaksud memberikan amanat kepada ahlinya, yaitu orang yang benar-benar mempunyai keahlian dibidang tersebut.

Sumber daya insani mestilah memahami mengapa ia diciptakan dan dijadikan khalifah dimuka bumi. Tidak lain tidak bukan adalah untuk mengelola bumi sebaik mungkin untuk mencapai kesejahteraan bersama. Untuk itu diperlukan karakteristik yang mendukung tugas itu. Karakteristik itu diilhami oleh sifat para nabi yang dapat disingkat menjadi SIFAT (Shiddiq, Itqan, Fathanah, Amanah dan Tabligh). Karakteristik itu berada pada cangkangnya yaitu pada sumber daya insani yang memiliki jasmani yang sehat dan ilmu yang memadai. Dengan demikian sumber daya insani ini dapat menjalankan tugas mulianya dalam memajukan ekonomi syariah yang dalam konteks ini menuju Indonesia yang sejahtera.

\section{Penelitian Terkait}

Mulai tahun 1991 sejak berdirinya lembaga keuangan syariah pertama di Indoensia, penelitian tentang ekonomi Islam sudah banyak dilakukan seiring dnegan perkembangan ekonomi Islam di Indonesia. Namun penelitian terkait dengan pendidikan ekonomi Islam dirasa masih sangat minim, baru setelah ekonomi Islam kini kian berkembang penelitian terkait pendidikan ekonomi Islam mulai sering digalakkan. Salah satu penelitian yang pernah ada adalah penelitian dengan judul "Pengembangan Kurikulum Ekonomi Islam di Perguruan Tinggi Agama Islam” oleh M. Akhyar Adnan dan Muhamad yang banyak membahas peta kurikulum ekonomi Islam dan pola pengembangan ekonomi Islam praktis, dengan harapan pengelompokan tersebut dapat menjadikan mata kuliah ekonomi syariah dapat berdiri sendiri. Selain itu Heri Sudarsono dalam penelitiannya yang berjudul "Kurikulum ekonomi Islam Berbasis Kompetensi” ia menyatakan bahwa Kurikulum ekonomi Islam dan atau perbankan/ keuangan syariah (EI\&KS) di sekolah tinggi (ST) dan perguruan tinggi (PT) dipengaruhi oleh sejarah ekonomi dan keuangan syariah di Indonesia. Karakter kurikulum ekonomi Islam yang digunakan oleh konsentrasi, prodi atau fakultas bisa terpengaruh dengan perkembangan liberalisasi pendidikan yang menjadi kecenderungan umum di Indonesia Apalagi SK Mendiknas mengenai Kurikulum Berbasis Kompetensi sebagai senjata bagi ST \& PT untuk membuat peluang-peluang secara institusional untuk membuat kurikulum yang sesuai dengan kehendak pasar.

Dari tinjauan diatas belum terlihat dengan jelas bagaimana proses pendidikan ekonomi syariah yang berintegrasi pelajaran ekonomi syariah yang dimulai di tataran sekolah menengah atas dengan ekstrakulikuler koperasi siswa

\section{METODE PENULISAN}

\section{Teknik Pengumpulan Data}

Data yang dimpulkan meliputi data sekunder yang berasal dari internet, jurnal penelitian, hasil survei, buku referensi atau artikel-artikel ilmiah dari sumber yang kredibel. 
Teknik pengumpulan data dengan cara input data yang dikumpulkan meliputi data sekunder yang berasal dari jurnal penelitian dan hasil survei baik cetak maupun elektronik (internet), literatur buku maupun dari situs-situs koran online. Proses menganalisis data yang terkumpul yang berkaitan dengan permasalahan yang diangkat dalam karya tulis dan output yaitu penyajian data berupa makalah karya tulis.

\section{Teknik Analisis Data}

Analisis mengenai aplikasi sistem pengintegrasian pendidikan ekonomi syariah dengan ekstrakulikuler koperasi pondok pesantren sebagai upaya strategis untuk mengajarkan ekonomi syariah lebih dini kepada generasi muda di lingkungan pondok pesantren dan juga turut membantu rencana strategis pemerintah yang dalam meningkatkan sumber daya insani yang mapu berdaya saing untuk percepatan pertumbuhan dan peningkatan sistem standar kompetensi lulusan pondok pesantren.

\section{PEMBAHASAN}

\section{Pentingnya Ekonomi Syariah Dalam Kulrikulum Muatan Lokal SMA Se-Derajat di Pondok Pesantren}

Patut kita syukuri bersama bahwa di Indonesia keberadaan institusi kelembagaan yang berbasis syariah semakin menjamur, khususnya perbankan syariah. Hal ini menunjukkan ketertarikan masyarakat Islam tentang Ekonomi Syariah semakin kuat Namun problema besar terjadi ketika kita di Tanya tentang kesiapan dan ketersediaan Sumber Daya Manusia (SDM). Selain secara kuantitas belum mencukupi kebutuhan mengingat begitu pesatnya laju perkembangan ekonomi syariah, juga kualitas dan kualifikasi belum memenuhi standar SDM Ekonomi Syariah yang ideal. Hal yang sering ditemukan bahwa umumnya SDM Perbankan Syariah merupakan pindahan dari Perbankan Konvensional.

Jika hanya mengandalkan pendidikan yang hanya membahas Ekonomi Syariah secara parsial saja, hasilnya pun dipastikan hanya bersifat formalitas. Padahal penerapan Ekonomi Syariah membutuhkan pemahaman, penjiwaan, dan proses internalisasi terhadap unsur-unsur yang terstruktur dalam konsep Ekonomi Syariah, dimana tiak mungkin dipahami dengan baik jika hanya melalui pengajian-pengajian yang belum tentu sistematis. Alasan tersebut di atas semakin mendorong pentingnya memasukkan mata pelajaran Pendidikan Ekonomi Syariah sebagai salah satu muatan lokal di Sekolah Menengah Atas untuk membentuk kualitas SDM yang mumpuni dalam Ekonomi Syariah karena telah dpersiapkan sejak dini. Secara eksplisit pembelajaran ekonomi Islam terdiri dari dua macam yaitu mu'amalah Islamiyah dan teori ekonomi praktis. Keseimbangan diantara 2 hal inilah yang sedang dicari dalam pemenuhan SDI ekonomi syariah kini.

Dalam kajian ushul figh fungsi mu'amalah Islamiyah harus tetap berdasarkan konsep Tauhid yang baku. Artinya Tauhid dan nilai agama harus terlebih dahulu ditanamkan pada para peserta didik seperti rukun iman maupun rukun Islam. Lalu untuk menjembatani antara teori mu'amalah Islamiyah dengan teori ekonomi praktis dihubungkanlah melalui peran ilmu sosial dalam kehidupan sehari-hari. Dari sinilah ilmu ekonomi dapat dipahami secara maknawi karena ia dikembalikan kepada "ibu kandungnya" dulu yaitu ilmu sosial sehingga 
praktek ekonomi dapat berjalan sesuai dengan nurani, tidak bersifat individualistik dan murni untuk kemaslahatan bersama.

Dan apabila mu'amalah Islamiyah sudah masuk pada ranah ekonomi, tentu akan mengalami pengembangan yang cukup dinamis karena praktek ekonomi selalu berjalan dinamis sesuai dengan perkembangan zaman. Namun walaupun kurikulumnya dapat berubah, namun dalam menyiapkan mutu SDI yang produktif, terdapat parameter yang dapat digunakan dengan rumusan konseptual diantaranya sebagai berikut: Peningkatan kualitas iman dan takwa, peningkatan kualitas hidup, peningkatan kualitas kerja, peningkatan kualitas karya, peningkatan kualitas pikir.

Semua parameter diatas diharapkan mampu menghasilkan SDI yang memiliki pengetahuan dan pemahaman yang seimbang antara hukum Islam dan praktek ekonomi. Dengan tujuan peserta didik dapat memiliki komitmen yang kuat untuk menerapkan prinsipprinsip syariah tidak hanya disaat ia bekerja tetapi juga dalam kehidupan sehari-hari artinya ia dapat berilmu dalam bekerja, bekerja dengan ilmu dan memiliki akhlak untuk mengetahui, memahami dan menghayati pekerjaannya.

\section{Pola Konsep Pengintegrasian Pendidikan Ekonomi Syari'ah dengan Ekstrakulikuler Koperasi Pondok Pesantren}

Pada rentang waktu tahun 2005-2010, saat ini share karyawan di lembaga keuangan syariah yang berlatar belakang pendidikan SMA mencapai 18\%. Aplikasi pendidikan ekonomi syariah pada lembaga pendidikan sekolah menengah atas begitupun di pondok pesantren amatlah berbeda dengan dengan program pendidikan pada perguran tinggi. Tatkala SMA lainnya cenderung takut akan kekurangan industri yang bisa menyerap lulusan yg dihasilkan, SMA dengan pola kurikulum ekonomi syariah sangat memiliki prospek yang cerah jika dipandang dari kaca mata industri keuangan syariah yang memang sedang gegap gempitanya di negeri ini. Pertumbuhan ekonomi syariah yang masif di negeri ini pastinya akan mampu untuk menampung lulusan yang terampil dalam bidang ekonomi syariah. Apalagi faktor pemilihan penanaman pengetahuan ekonomi syariah sejak dini sebagai pilot project dalam hal pendukung atmosfer pendidikan, maka akan dapat semakin mempermudah penyampaian bahan ajar ekonomi syariah. Oleh karena itu, Hal ini dirasa cukup prospektif untuk menjadikan pesantren sebagai tempat awal guna mencetak sumber daya insani lebih dini namun tidak prematur dan tetap berkualitas.

Konsep ini memerlukan sinergisitas dari berbagai macam stakeholders. Misalnya saja untuk garis koordinasi antara Diknas, Depag dan IAEI. Ketiga elemen tersebut bekerjasama dalam penyusunan kurikulum dan juga dalam hal penempatan SDI pengajarnya. Dua hal tersebut dalam hal ini sangatlah vital peranannya. kurikulum sangat diperlukan, karena meskipun suatu institusi punya pengajar yang berkualitas namun jika tanpa adanya guidance dari kurikulum, maka akan terjadi misorientasi dalam upaya pendidikan tersebut atau bisabisa lulusannya tidak memenuhi persyaratan dunia kerja. Sama juga halnya dengan SDI pengajar yang tangguh. Apalah artinya mempunyai kurikulum yang komprehensif dan canggih namun jika pengajarnya tidak mampu untuk menyampaikan materi yang diamanahkan kurikulum dengan baik. Adapun penjelasan konsep pengintegrasiannya tersebut sebagaimana terpampang pada gambar. Konsep tersebut memerlukan sinergisitas 
dari berbagai macam stakeholders. Misalnya saja untuk garis koordinasi antara Diknas, Depag dan IAEI. Ketiga elemen tersebut bekerjasama dalam penyusunan kurikulum dan juga dalam hal penempatan SDI pengajarnya.

Dua hal tersebut dalam SMA ini sangatlah vital peranannya. kurikulum sangat diperlukan, karena meskipun suatu institusi punya pengajar yang berkualitas wahid namun jika tanpa adanya guidance dari kurikulum, maka akan terjadi misorientasi dalam upaya pendidikan tersebut atau bisa-bisa lulusannya tidak memenuhi persyaratan dunia kerja. Sama juga halnya dengan SDI pengajar yang tangguh. Apalah artinya mempunyai kurikulum yang komprehensif dan canggih namun jika pengajarnya tidak mampu untuk menyampaikan materi yang diamanahkan kurikulum dengan baik. Maka dari itu kurikulum dan tenaga pengajar adalah dua hal penting yang hendaknya terlebih dahulu dipenuhi oleh SMA dengan pendidkan ekonomi syariah tersebut. Setelah koordinasi antara tiga elemen tersebut, maka SMA pun selaku eksekutor dari masterpiece ini akan dapat menjalankannya dengan baik. Tapi tidak cukup sampai disitu saja, ekstrakulikuler koperasi siwa sebagai wadah penyaluran keilmuan secara aplikatif yang memberikan pengetahuan praktis operasional pada anggota koperasi khususnya para murid-murid yang tegabung didalamnya. Peran Lembaga keuangan Mikro Syariah (LKMS) atau bahkan Lembaga Keuangan Syariah (LKS) sebagai tempat untuk melatih para siswa dala aspek manajemen operasional pada koperasi siswa alias trainer bagi para murid SMA untuk lebih competible dalam menjalankan roda operasional koperasi siswa. Bukankah pepatah mengatakan "Practice Makes Perfect". Maka dari itu, agar siswa mempunyai pemahaman yang baik, hendaknya juga proses pembelajaran tidak hanya berupa aspek kognitif saja tetapi juga dari segi aspek psikomotorik.

Output dari pengintegrasian pendidikan ekonomi syariah dengan ekstrakulikuler koperasi siswa tersebut nantinya selain bisa langsung terjun menjadi pelaku di lembaga bisnis syariah dan juga tidak menutup kemungkinan bagi lulusan SMA yang menerapkan hal tersebut untuk meneruskan pendidikannya ke jenjang Perguruan Tinggi. Sehingga ada standar kompetensi lulusan dari SMA yang telah mengintegrasikan pendidikan ekonomi syariah. Pertama menganalisis permasalahan ekonomi dalam kaitannya dengan kebutuhan manusia dan sistem ekonomi konvensional dan Islam. Kedua, mendeskripsikan kegiatan ekonomi produsen, konsumen, permintaan, penawaran dan harga keseimbangan melalui mekanisme pasar. Ketiga, mendeskripsikan kebijakan pemerintah dalam bidang ekonomi dalam kaitannya dengan pendapatan nasional, konsumsi, tabungan, bantuan sosial, investasi, uang dan perbankan baik yang syariah maupaun yang konvensional. Keempat, memahami pembangunan ekonomi suatu negara dalam kaitannya dengan ketenagakerjaan, transparansi APBN, pasar modal baik yang syariah maupun yang konvensional dan ekonomi terbuka. Kelima, menyusun siklus akuntansi perusahaan jasa dan perusahaan dagang dan pengenalan tentang akuntasi syariah. Keenam, memahami fungsi-fungsi manajemen badan usaha, koperasi dan kewirausahaan serta penganalan manajemen syariah.

Satu lagi strategi agar eksistensinya tersebut tetap berkibar adalah dengan membuat industrinya lembaga keuangan sendiri. Hal tersebut bisa diwujudkan dengan memperluas jaringan kerja koperasi siswa dengan lembaga sejenis di luar sekolah. Jumlah yang banyak 
sekalipun dari siswa SMA tidak akan menjadi masalah karena hal tersebut dapat memperkokoh keberadaan SMA tersebut walaupun industri itu menengah kecil.

Hal tersebut juga dibutuhkan dukungan moral maupun modal dari para stakeholder sekolah. Keterlibatan semua komponen sekolah perlu ditumbuhkan. Bila proses ini dapat berjalan dengan baik, maka dapat dipastikan setiap siswa yang telah banyak mengenyam pelajaran ekonomi syariah secara teoritis akan lebih bermanfaat ketika teori yang didapat

langsung di aplikasikan pada koperasi siswa sehingga menghsilkan lulusan SMA yang tidak hanya jago dalam hal teoritis tapi juga dalam tataran praktis. Dengan cara semacam ini maka program pemerintah memperbanyak jumlah koperasi siswa dalam rangka perluasan akses,peningkatan mutu dan pencitraan publik dapat terwujud dengan baik.

Untuk mempertajam alasan perlunya program ini maka kami menggunakan pola analisis SWOT. Dimana hasil analisisnya dalah sebagai berikut: Strengt (kekuatan), Weakness (Kelemahan), Opportunities (Peluang) dan Threat (Ancaman).

Strength (Kekuatan) pada praktek program pengintegrasian pendidikan ekonomi syariah dengan eksrakurikuler koperasi pondok pesantren, maka dapat diperoleh berbagai manfaat positif. Diantara seperti dapat munculnya calon penurus bangsa yang berkompetensi, memiliki daya saing tinggi, mampu menguatkan ketahanan nasional, menumbuh kembangkan pemikiran kreativitas dalam bisnis dan membentuk ikatan emosional secara non formal dengan kuat. Karena telah terbekali pengetahuan ekonomi syariah secara sistematis teoritis dan aplikasi praktis kelembagaan keuangan syariah .

Weakness (Kelemahan) dalam program ini adalah sulitnya dalam hal penerapan. Karena sejak saat ini masyarakat kita cenderung sibuk sendiri, oportunis, dan konsumeris. Sehingga banyak dari tokoh masyarakat menunggu bukti dulu dari program ini baru mereka mau bekerja sama dan mendukung kegian ini.

Opportunities (Peluang) dalam program ini masih cukup tinggi. Karena perkembangan keilmuan ekonomi syariah terus berkembang dengan banyaknya Perguruan Tinggi yang telah menjalankan pendidikan ekonomi syariah ditingkat perkuliahan dan berkembangnya lembaga keuangan syariah. Sehingga pembekalan keilmuan ekonomi syariah sejak dini dapat terlaksana dengan optimal.

Threat (Ancaman) bisa jadi ketika beberapa orang berkepentingan (kaum kapitalis) mengetahui konsep ini. Maka ada kalanya program ini dihalang-halangi untuk tujuan meminimalisir munculnya pesaing-pesaing dini (muda). Dan memang bukan hal yang mudah untuk menjadi tenaga kerja unggulan di pasar kerja internasional. Namun hal tersebut bukanlah hal yang mustahil bagi para pelajar. Apalagi jika nantinya lulusan SMA yang sudah plus-plus dapat melanjutkan pendidikannya ke jenjang yang lebih tinggi lagi, yakni di PT sebagaimana diilustrasikan pada gambar. Apalagi jika dapat melanjutkan pendidikan ke luar negeri, lulusan SMA ini akan sangat mumpuni untuk ke depannya. Artinya, harga jasa keahlian yang diberikannya pun akan semakin tinggi pula di pasar kerja internasional. Dengan begitu, kita akan bisa berjaya di "kandang" sendiri. Karena jika kita tidak bisa menyiapkan generasi ekonomi syariah sedini dan seunggul mungkin. Bukan hal yang tidak mungkin jika suatu saat nanti industri ekonomi syariah di Indonesia khususnya Madura berkembang sangat 
pesat dan besar namun SDI didalamnya adalah orang-orang asing yang memiliki kapabilitas yang lebih daripaa orang Indonesia sendiri.

\section{Kesimpulan}

Berdasarkan data dan pembahasan yang telah dilakukan, kesimpulan dari penelitian ini bahwa merintis upaya penanaman ekonomi syariah lebih dini pada level sekolah menengah tidaklah semudah membalik telapak tangan, dikarenakan belum adanya kurikulum dan terbatasnya SDI pengajar yang mempunyai kualifikasi keilmuan yang integral. Sekolah SMA berbasis koperasi pondok pesantren yang saling berintegrasi bertujuan untuk melahirkan calon pelaku industri yang unggul dan siap kerja setelah lulus. Konsep pengintegrasian pendidikan ekonomi syariah dengan ekstrakulikuler koperasi siswa adalah upaya strategis untuk melahirkan SDI muda nan tangguh dalam bidang ekonomi syariah. Hal ini dikarenakan pemilihan dalam penerapan teoritis secara aplikatif sebagai pilot project dianggap sangat mendukung iklim pengajaran ekonomi syariah.

\section{Daftar Pustaka}

Ahyar, M. K. (2018). Literasi Keuangan Syariah Dan Pondok Pesantren (Studi Kasus Pondok Modern Asy-Syifa Balikpapan). Islamiconomic: Jurnal Ekonomi Islam. Https://Doi.Org/10.32678/Ijei.V9i2.107

Basri, S., Samin, B., \& Beik, I. S. (2019). Peran Kurikulum Ekonomi Syariah Untuk Pencapaian Kemakmuran Dan Kesejahteraan. Ta'dibuna: Jurnal Pendidikan Islam. Https://Doi.Org/10.32832/Tadibuna.V811.1340

Effiyanti, T., Pratiwi, D. E., \& Dalimunthe, M. B. (2018). Pengembangan Perangkat Pembelajaran Berorientasi Kkni Pada Mata Kuliah Ekonomi Syariah. Niagawan. Https://Doi.Org/10.24114/Niaga.V7i1.9354

Muliadi, S. (2018). Ekonomi Islam Dan Maqasid Syariah Dalam Kurikulum Ekonomi Islam Di Perguruan Tinggi Selamat Muliadi Fakultas Ilmu Agama Islam, Universitas Islam Indonesia Yogyakarta. Islamiconomic: Jurnal Ekonomi Islam.

Muliadi, S. (2018). Epistemologi Ekonomi Islam Dan Maqasid Syariah Dalam Kurikulum Ekonomi Islam Di Perguruan Tinggi. Islamiconomic: Jurnal Ekonomi Islam. Https://Doi.Org/10.32678/Ijei.V9i2.102

Niswatin, N., Hasiru, R., \& Rasuli, L. O. (2017). Pengembangan Kurikulum Ekonomi Dan Akuntansi Syariah Di Sekolah (Studi Atas Persepsi Guru Dan Siswa Di Sma Kota Gorontalo). Al-Ulum. Https://Doi.Org/10.30603/Au.V17i1.41

Qaradhawi Yusuf. (2002). Teologi Kemiskinan, Penj. A. Maimun Syamsuddin Dan A. Wabid Hasan. Yogyakarta: Mitra Pustaka.

Unggul, P. (2016). Pariwisata Syariah Prospek Dan Perkembangan. Yogyakarta: Upp Stim Ykpn. 